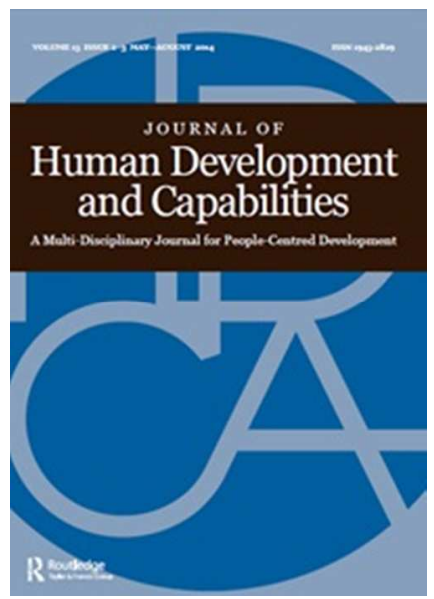

\title{
How to Build Collective Capabilities: The 3C-Model for Grassroots-led Development
}

\begin{tabular}{|r|l|}
\hline Journal: & Journal of Human Development and Capabilities \\
\hline Manuscript ID & CJHD-2015-0142.R2 \\
\hline Manuscript Type: & Special Issue Article \\
\hline Keywords: & $\begin{array}{l}\text { Collective agency, Sustainable human development, Collective capabilities, } \\
\text { Grassroots-led development, social innovation }\end{array}$ \\
& $\begin{array}{l}\text { Capabilities need to be built from the bottom-up. Social innovations at the } \\
\text { grassroots seek to present new solutions to existing social problems. } \\
\text { However, since the poor suffer from limitations on their individual } \\
\text { capabilities and agency, they engage in acts of collective agency to } \\
\text { generate new collective capabilities that each individual alone would not be } \\
\text { able to achieve. The question is: how can these acts of collective agency be } \\
\text { initiated, supported and sustained in practice? What roles can development } \\
\text { actors (such as the state, donors and NGOs) play in supporting these } \\
\text { acts of collective agency? Drawing on the literature on social innovation, } \\
\text { the capability approach, participation and empowerment, the paper argues } \\
\text { that three crucial C-processes are integral conditions for promoting } \\
\text { successful, scalable and sustainable social innovations at the } \\
\text { grassroots, namely: (1) Conscientization; (2) Conciliation and (3) } \\
\text { Collaboration. By linking the individual, collective and institutional levels of } \\
\text { analysis, the paper demonstrates the importance of individual behavioural } \\
\text { changes, collective agency and local institutional reforms for the success, } \\
\text { sustainability and scalability of social innovations at the grassroots. The } \\
\text { paper acknowledges conflict, capture and cooptation as potential } \\
\text { limitations and recognizes the role of contextual factors in } \\
\text { initiating, implementing and sustaining social innovations at the } \\
\text { grassroots. }\end{array}$ \\
\hline Abstractions
\end{tabular}




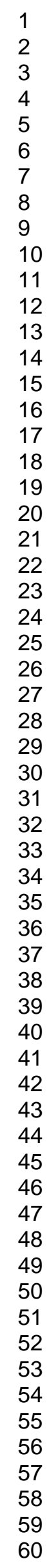

SCHOLARONE"

Manuscripts

25

26

27

29

30 


\title{
How to Build Collective Capabilities: The 3C-Model for Grassroots-led Development
}

\begin{abstract}
Capabilities need to be built from the bottom-up. Social innovations at the grassroots seek to present new solutions to existing social problems. However, since the poor suffer from limitations on their individual capabilities and agency, they engage in acts of collective agency to generate new collective capabilities that each individual alone would not be able to achieve. The question is: how can these acts of collective agency be initiated, supported and sustained in practice? What roles can development actors (such as the state, donors and NGOs) play in supporting these acts of collective agency? Drawing on the literature on social innovation, the capability approach, participation and empowerment, the paper argues that three crucial Cprocesses are integral conditions for promoting successful, scalable and sustainable social innovations at the grassroots, namely: (1) Conscientization; (2) Conciliation and (3) Collaboration. By linking the individual, collective and institutional levels of analysis, the paper demonstrates the importance of individual behavioural changes, collective agency and local institutional reforms for the success, sustainability and scalability of social innovations at the grassroots. The paper acknowledges conflict, capture and cooptation as potential limitations and recognizes the role of contextual factors in initiating, implementing and sustaining social innovations at the grassroots.
\end{abstract}

\section{Keywords:}

Collective agency, Sustainable human development, Collective capabilities, Grassroots-led development, social innovation

\section{Introduction}

Over the past two decades, great interest has been expressed in promoting people-centred development (UNDP Human Development Reports 1990-2015; Sen, 1999), empowering local communities (Alsop et al, 2006; Alsop and Heinsohn, 2005; Narayan 2002; 2005), making the reality of the poor come 'first' (Chambers, 1997), listening to the voices of the poor (Narayan, 2000a; b), limiting the effects of 'tyrannical' participatory approaches (Cooke and Kothari, 2001; Cleaver, 1999; Cornwall, 2002) and scaling-up the impact of NGO work in order to render it more effective (Edwards and Hulme, 1992; Korten, 1987). Despite this widely available literature on power dynamics (Rowlands, 1997; Gaventa, 2006; Ibrahim and Alkire, 2007), empowerment (Alsop et al, 2006; Narayan, 2000; 2005; Friedmann, 1992) and participation (Chambers, 1993; 1997; Cornwall, 2008), only a few studies (Ziegler et al, 2013; Ziegler, 2013; Seyang and Smith, 2007) explore social innovations at the grassroots. These studies mostly adopt a case study approach to explain the dynamics of social innovation processes and the factors that affect them.

Building on this literature, the aim of this paper is to present a new model for social innovation at the grassroots that reframes and reconceptualises grassroot processes and their dynamics. Which processes are necessary to render social innovations at the grassroots more successful, scalable and sustainable? To answer this central research question, the model presented identifies three Cprocesses (conscientization, conciliation and collaboration) as integral conditions needed to promote and sustain social innovations at the grassroots. Instead of presenting case studies for social innovation per se, the paper adopts a new framework that explains the dynamics of each of the three C-processes, explores their interlinkages and identifies the various factors that can affect them. Recognising the role of contextual factors in influencing the success, scalability and sustainability of social innovations, the model presented not only shows that context matters; but also explains how it matters. 
The need to develop such a model has been expressed, for example, by national governments who seek to empower marginalised groups and tackle structural inequalities. For example, with the Big Society initiative, the UK government recently encouraged "the move towards smaller government" and as a result "placed the onus on communities to creatively tackle their own problems" (Chalmers, 2012, p.17). Local and international NGOs as well as donor agencies also aim to support and scale-up grassroots-initiatives to enhance the relevance and impact of their development work. New ways of thinking and 'doing development differently' have been promoted to ensure that grassroots-led processes are not simply localised unsustainable solutions, but can be a means for empowering local communities and inducing sustainable social change. The question however remains: How can these initiatives become vehicles for social innovation at the grassroots level?

To address this question, section 1 presents the model and links it to the literature on social innovation. Section 2 explains the conceptual foundations of the model by adopting the capability approach as an evaluative framework and drawing on the literature on empowerment, participation, agency and structure. Section 3 briefly explains how the model was developed and examines the dynamics of conscientization, conciliation and collaboration processes and the contextual factors that affect them. Section 4 discusses the limitations of the model and explains how its success, sustainability and scalability can be promoted. The concluding section illustrates the relevance of the model for policymaking.

\section{The 3C-model for Social Innovation?}

\section{The 3C-model}

Building on the literature on social innovation, the capability approach, empowerment and participation, the aim of this model is to bridge the gap between theory and practice by presenting a new framework for conceptualising and operationalising grassroots-led development. Grassroots-led development (GLD) is defined as an improvement in one or more aspects of human wellbeing brought about by people acting as initiators and agents of change (in collaboration with other development actors/institutions) at the grassroots. The new 3C model for grassrootsled development emphasizes the importance of three processes, namely: (1) Conscientization; (2) Conciliation; and (3) Collaboration. The three identified processes promote social change at three highly interdependent levels: the individual, collective and institutional levels. By exploring the dynamics of each of these processes and examining the factors that affect them, the model demonstrates the importance of individual behavioural changes, collective agency and local institutional reforms for social innovations at the grassroots. This framework not only explores the 'bow' question, i.e. the dynamics of each of the 3C processes and how they can be initiated and supported, but also examines their impact. To do so, it stresses three evaluative aspects of GLD namely, (1) Success (i.e. achievement of objectives), (2) Sustainability (i.e. focus on long-term impact) and (3) Scalability (i.e broader institutionalisation rather than one-off solutions).

Figure 1 shows how social innovations at the grassroots can be successful, sustainable and scalable when they: (1) induce positive behavioral changes at the individual's level through conscientization; (2) support acts of collective agency at the communal level through conciliation; and (3) promote local reforms at the institutional level through collaboration. The process of conscientization encourages citizens to think critically about their realities and nurtures their 'capacity to aspire' for better lives. The conciliation process blends individual and collective interests rendering them mutually reinforcing rather than conflicting. Through conciliation, a common vision is created to guide the acts of collective agency. Finally, collaboration between local communities and other actors, such as the state, local NGOs and donor agencies, is crucial 
for challenging the existing unequal power relations among and between these 'partners'. Through these partnerships, the sustainability, scalability and success of social innovations at the grassroots can be promoted.

\section{Insert Figure 1 here}

\section{Why the 3C-model for Social Innovation?}

After briefly presenting the new model and its components; this section explains why the model is one of social innovation at the grassroots. "Generally speaking, no agreed definition of 'social innovation' exists" (Pol and Ville, 2009, p.881). That is why it has been perceived as a 'fuzzy concept' (Cunha et al, 2015) or buzzword (Pol and Ville, 2009). Scholars have sought to define the concept of social innovation (Dawson and Daniel, 2010; Mulgan et al., 2006; 2007; Phills et al, 2008), critically review its definitions (Nilsson, 2003; Goldenberg et al., 2009; Nicholls and Murdock, 2012), present theoretical models to conceptualise it (Goldstein et al, 2010; Mulgan, 2006), or explore it by comparing it to social entrepreneurship and social enterprises (Cunha et al., 2015; Bonifacio, 2014; Seyfang \& Haxeltine, 2012; Perrini, Vurro, \& Costanzo, 2010; Chalmers, 2012). Others have distinguished between the normative and analytic definitions of social innovation and analyzed the term 'social' (Howaldt and Schwarz, 2010; Ziegler, 2010; Mair and Marti, 2006). A number of empirical studies have also examined the dynamics of social innovation processes (Klein et al, 2010; Hamalainen and Heiskala, 2007; Holmes and Smart, 2009; Gonzalez and Healey, 2005).

In this literature, there is wide agreement that social innovation is linked to new solutions that challenge the status quo and aim to induce institutional change; to promote the 'public good' and to address these social needs that cannot be addressed by the market (Pol and Ville, 2009; Phills et al., 2008). Social innovation is thus viewed as a process of social value creation at the grassroots (Sharra and Nyssens, 2010; Moulaert and Nussbaumer, 2005). Although there is no agreed upon definition of social innovation, the process itself is viewed as a "novel solution to a social problem that is more effective, efficient, sustainable or just than existing solutions" (Phills et al., 2008, p.39). According to Dawson \& Daniel (2010, p. 15 [emphasis added]), social innovation is "a collective dynamic interplay across the technical, social, economic and political dimensions in the group pursuit and development of social objectives and outcomes".

Linking the capability approach and social innovation, this paper recognizes the role of social innovations for the "carrying out of new combinations of capabilities" (Ziegler, 2010, p. 256). It adopts the EU's definition of social innovation as the "development and delivery of new ideas and solutions $\ldots$ at different socio-structural levels that intentionally seek to change power relations and improve human capabilities as well as the processes via which these solutions are carried out" (Houghton Budd et al, 2015, p.3). This definition of social innovation suits the 3C model given its focus on human capabilities, power dynamics as well as the processes that lead to social change. The model is one for social innovation because it identifies three necessary processes needed for the generation of new individual and collective capabilities, for the reconfiguration of unequal power relations and for the promotion of sustainable institutional reforms at the grassroots.

As for the typology of social innovations, scholars distinguish between three types of innovations: 'pure business innovations'; 'bifocal' innovations (Pol and Ville, 2009) or 'pure' social innovations (Borzaga and Bodini, 2014). The proposed 3C model applies mainly to 'pure' social innovations, which seek to address those needs that the market or the state failed to address. Mair and Marti (2009) present such an example through BRAC's Ultra Poor programme in order to show how 
social innovation can fill in the existing gap created by institutional voids and market failures. Thus, whilst social change can be induced either through top-down policies or citizens' action (Chiappero-Martinetti and Von Jacobi, 2015), the focus of the model proposed here is primarily on social innovations that seek to promote social change and address market and state failures from the bottom-up.

Although social innovation was initially viewed as a localized solution, "it is only in most recent times that social innovation has developed a significant public policy foothold" (Chalmers, 2012, p.20). There is nowadays a growing consensus that social innovations are indeed relevant for policy development (Borzaga and Bodini, 2014). Whilst the wider literature on social innovation focuses on its definitions, conceptualization and application, "relatively little attention is being paid to the actors and mechanisms that bring it about" (Borzaga and Bodini, 2014, p.412[emphasis added]). The $3 \mathrm{C}$ model seeks to address this gap by identifying three processes that can initiate and sustain social innovations at the grassroots. In line with Seyfang and Haxeltine (2012, p.381), this framework is a "community-based, action-oriented model of social change (in preference to a cognitive theory of behavior change)". It is not only a conceptual framework for understanding social innovation and its dynamic processes, but is also a practical guide for actors to design, plan, implement and support sustainable, successful and scalable social innovations at the grassroots.

Building on previous work that sought to present models of social innovations at the grassroots and to explore the barriers that affect these innovations (Mendes et al, 2012; Chalmers, 2012; Biggs, et al, 2010; Seyfang and Smith, 2007), the 3C-model seeks to contribute to the literature on social innovation in three ways. First, the model provides a dynamic picture of three processes that are integral to social innovation at the grassroots. Instead of focusing merely on actors and outcomes, the model emphasizes three processes of social innovation at the grassroots and explores their dynamics and interlinkages. Social innovation is mainly about the process of change itself and how a new reality is created (Cunha et al, 2015; Sharra and Nyssens, 2010). Despite its importance, however, "very little attention is being paid to... the process that leads to social innovation ('how' social innovation happens), and the characteristics of the actors or organisations that carry it out (who' can best deliver social innovation)" (Borzaga and Bodini, 2014, p.415). The 3C model addresses this gap by identifying and 'unpacking' three processes (conscientization, conciliation and collaboration) that can lead to sustainable, successful and scalable grassroots innovations.

Second, despite its wide range, the literature on social innovation is characterised by conceptual confusion. Expressing this conceptual confusion, Cunha et al (2015) explains how people have been mixing up different ideas, theories and phenomena when exploring social innovation processes. The proposed model seeks to address this conceptual confusion by proposing a clearer framework for conceptualising social innovation at the grassroots. It primarily focuses on three 3C processes that - it argues - are essential and integral for the sustainability, scalability and success of grassroots innovations. Other scholars (Moulaert \& Nussbaumer, 2005; Moulaert, et.al, 2007; Moulaert et al., 2005) also sought to explore social innovation processes; but their studies were mainly focused on particular challenges, such as urban development, regeneration and social cohesion. The proposed 3C model, however, is not domain-specific as it presents a new framework that can be applied to social innovations that seek to address various challenges at the grassroots.

Third, instead of providing a 'snapshot' of how social innovation occurs at the grassroots, the circular interactive nature of the model and its components blurs the differentiation between means and ends. This is crucial insofar as social innovations are defined as such "both in their ends and in their means" (Murray et al, 2010, p.3). Each of the 3C-proceses is thus both a means and an 
end for promoting social innovation. These processes are, on the one hand, a means for widening individual freedoms and collective capabilities, and on the other hand, ends with intrinsic value.

The 3C-processes identified in our proposed model resonate with elements of other models; such as those developed by Beckert (2010); and Gonzalez and Healey (2005). The latter have developed a model to examine the micro-dynamics of governance transformations focusing on cognitive framing, the interactive relations between agency and structure, and the institutionalisation of policy discourses. Beckert (2010) has also identified three 'irreducible social forces' - (1) cognitive frames; (2) social networks; and (3) institutions - that are well-linked to the 3C-processes. Following suit, conscientization addresses cognitive frames, conciliation deals with issues of power and agency, and collaboration seeks to institutionalise grassroots innovations and reconfigure power relations among development actors. Building on these models, the $3 \mathrm{C}$ model aims to contribute to the literature on social innovation by going beyond economic outcomes and market dynamics to directly conceptualise and analyse the dynamics of social innovation processes at the grassroots.

Despite its focus on markets, Beckert's work is still relevant for the 3C model as "apart from providing a useful framework for the conceptualisation of social forces, Beckert's hypotheses about dynamics seem to be relevant in order to identify the emergence of spaces (opportunities) for social innovation processes" (Chiappero-Martinetti and Von Jacobi, 2015, p.3-4 [emphasis in original]). Although 'capital' can be considered as a missing ' $\mathrm{C}$ ' in our proposed model, the model does not undermine the market as an "important social structure and a mechanism to foster social and economic development" (Mair and Marti, 2009, p.422). This role is recognized but intentionally underplayed because markets are either absent or weak in developing countries due to the various institutional impediments that restrict market participation; especially at the grassroots (Mair and Marti, 2009; Easterly, 2006). Therefore, while acknowledging the important role that markets can play in promoting social innovations, the $3 \mathrm{C}$ model focuses mainly on those processes that can help communities address the kind of social needs not 'taken on' by the market (Pol and Ville, 2009).

\section{Conceptual Foundations of the 3C model}

\section{Why the Capability Approach as Evaluative Framework?}

Given that the CA views people not only as the centre but also as the main agents of development (Sen, 1999), the 3C model adopts the capability approach (CA) as an evaluative framework for conceptualizing and assessing social innovations at the grassroots. The $3 \mathrm{C}$ model aims to demonstrate how individual and collective acts of agency can generate new collective capabilities at the grassroots.

By linking the individual, collective and institutional levels of analysis, the $3 \mathrm{C}$ model shifts the analysis of human capabilities from the individual to the collectivity (Ibrahim, 2006). It aims to show how social innovations can generate new collective capabilities from which all community members can benefit - even if to different degrees. Through collective agency and the pooling of personal responsibilities, new collective capabilities can be generated (Ibrahim, 2006; Ballet et.al., 2007; Pelenc et al, 2015). In contrast to group capabilities which are "the average of the capabilities (and sources of capabilities) of all the individuals in the selected groups" (Stewart, 2004, p.192), collective capabilities are more than the aggregation of individual capabilities. They result from collective action and their benefits accrue to the community at large and not to a single individual (Ibrahim; 2006). This is important, as social innovation processes create value 
that accrues "primarily to society as a whole rather than private individuals" (Phills et al., 2008, p.39 [emphasis added]). Sen (2009) does acknowledge the role of collective capabilities but rejects them arguing that they are mainly 'socially dependent capabilities' (Sen, 2002). Alkire (2008) and Volkert (2013) also presented several critiques of the concept. Despite these critiques (discussed in Ibrahim, 2013b), the proposed 3C model considers acts of collective agency essential for the generation of new collective capabilities.

Sen $(1985$, p.206) defines human agency as "what a person is free to do and achieve in pursuit of whatever goals or values he or she regards as important". Sen (1992) distinguishes between the individual's well-being and agency achievements; where the former is linked to one's own wellbeing; while the latter go beyond personal wellbeing to address broader goals that one has reason to value. Evans (2002) argued that collective action is indispensible for the achievement of human capabilities mainly because 'individual capabilities depend on collective capabilities' and 'organized collectivities .... are fundamental to people's capabilities to choose the lives they have reason to value" (Evans, 2002, p.56). Given the restrictions on individual agency, especially in deprived communities, the role of collective agency is therefore essential for promoting freedoms, choices and capabilities (Cleaver, 2007; Ibrahim, 2008; Tiwari and Ibrahim, 2012). Collective agency, however, cannot be imposed but needs to arise from a learning process (PahlWostl, 2006). To initiate and sustain acts of collective agency, it is therefore important to link between individual and collective agency and to explore the factors affecting both (Pelenc et al, 2015). Collective agency is viewed "as the capacity of the group to define common goals and the freedom to act to reach the chosen goals" (Pelenc et al, 2015, p.229). Using the case of Nijera Kori (NK) in rural Bangladesh, Kabeer (2003), for example, shows how collectivities are important for "building the collective capabilities of poor women and men to claim their rights as citizens rather than as clients" (Kabeer, 2003, p.3 [emphasis in original]). The 3C model thus aims to explore the dynamics of these acts of collective agency and to show how new collective capabilities can be generated through grassroots innovations. The next section explains how our model seeks to address a number of key debates in the literature on agency and structure and on participation and empowerment.

Addressing Agency and Structure

One of the aims of this model is to show how the 3C-processes link individual and collective agency (through conscientization and conciliation) with institutional structures (through collaboration). The proposed model transcends the dichotomy between agency and structure (Giddens, 1984) by explaining how agency can change structure and vice versa. Several scholars (Narayan, 2002; 2005; Alsop et.al. 2006; Alsop and Heinsohn, 2005) showed how empowerment depends on this interaction between agency and opportunity structure. (Giddens (1984, p.14) defines human agency as the capacity to make a difference, i.e. to have a transformative capacity, whilst structure include social systems and other reproduced social practices - which can have either constraining or enabling effects (Gidden, 1984; Rose and Scheepers, 2001). The exercise of agency is constrained by social structures (Giddens, 1984) and culture (Bourdieu, 1977; Douglas, 1987). The role of social innovation and the three identified processes is to initiate and sustain individual and collective agency. The problem, however, is that through embedded agency (Powell and DiMaggio, 1991; Friedland and Alford, 1991; Sewell, 1991; Holm, 1995; Seo and Creed, 2002) actors are subject to regulations, norms and cognitive frames that affect their individual and collective behaviour. Conscientization is therefore essential to help those actors to think critically about their lives and to help induce positive behavioural changes at the individual and collective levels. This is because the "embedding structures do not simply generate constraints on agency but, instead, provide a platform for the unfolding of entrepreneurial activities" (Garud et al., 2007, p.961 [emphasis added]). Battilana (2006) and Battilana and Boxenbaum 
(2009), for example, examined the conditions under which actors can engage in entrepreneurial activities and induce institutional changes. It is this interactive relationship between agency and structure that this model seeks to explore through the three C-processes. The model stresses the interactive relationship between individual and collective agency, on the one hand, and institutional and social structures, on the other. In addition, it examines the role that social innovations can play in affecting this relationship.

\section{Promoting 'Real' Participation and Empowerment}

The aim of the model is to explain how the 3C-proceses can promote, support and sustain grassroots innovations. A wide literature on participation and empowerment already exists (Rowlands, 1997; Gaventa, 2006; Ibrahim and Alkire, 2007; Alsop et al, 2006; Narayan, 2000; 2005; Friedmann, 1992; Chambers, 1993; 1997; Cornwall, 2002; 2008). Nevertheless, in practice development projects still include 'participatory and consultative' elements only in the form of 'invited participation' (Cornwall, 2002) rather than truly 'people-centred' processes. The notion of the 'development project' itself limits the ability of poor and marginalised groups from meaningfully participating (Cornwall, 2006), thus rendering empowerment and participation merely as 'buzzwords' (Cornwall and Brock, 2005). As a result, several scholars (Cooke and Kothari, 2001; Cleaver, 1999; Mansuri and Rao, 2004; Hickey and Mohan, 2004) have critiqued the nature and practice of 'participation as a new tyranny'. However, none of these critiques offered an alternative vision as to how 'real participation and empowerment' can be promoted at the grassroots. The aim of the $3 \mathrm{C}$ model is to fill this gap by explaining how individuals and communities can act as agents of change through conscientization and conciliation and how they can collaborate with other actors to challenge the existing power relations within the current aid systems. The idea is to move beyond the 'invited' spaces for participation; so that communities can create their own participatory spaces through grassroots innovations (Gaventa, 2006; Cornwall, 2002). These are places "in which like-minded people join together in common pursuits" (Cornwall, 2002, p. 24). These are spaces where 'real empowerment and participation' are promoted through grassroots initiatives, and sustained through conscientization, conciliation and collaboration processes.

With reference to Rowlands' (1997) famous categorization of power, the 3C-processes also address 'power' at the individual, collective and institutional levels. Conscientization addresses the power within, conciliation enhances power with, and collaboration emphasizes the importance of power over and power to challenge unequal power relations between local communities and other development actors. The model also helps us analyse how individuals and communities try to navigate through three different forms of power: visible, hidden and invisible (Gaventa, 2006; VeneKlasen and Miller, 2002). By raising the critical consciousness of individuals, helping them to form collectivities and linking them up with other development actors, grassroots innovations can thus help individuals and communities to address and challenge visible, hidden and invisible forms of power through behavioural changes, collective agency and local institutional reforms.

Change can happen either radically or incrementally. Oakley (2001) distinguishes between the power to induce radical change and the power - in a Freirian sense - to gain control. Our model adopts the latter view - focusing mainly on incremental social change through grassroots innovations. It is, however, acknowledged that social innovations can indeed "simultaneously enhance and disrupt the existing social order" (Nicholls and Murdock, 2012). Paradoxically, sometimes radical and disruptive changes can even lead to higher resilience rather than destruction (Lodemann and Ziegler, 2015). Nevertheless, the model advocates incremental social change that is gradually induced through the $3 \mathrm{C}$ processes at the grassroots. The following section explains the dynamics of each of these processes and the factors affecting them. 


\section{The Dynamics of the $3 \mathrm{C}$ model:}

\section{How the model was developed}

The aim of this paper is primarily a conceptual one; hence this section will only briefly explain how the model was developed and will provide the background to some of the empirical data presented later in this section. The model was developed as a result of two rounds of data collection conducted in Egypt over a ten year period (2006-2016). Adopting a qualitative research design, the model was developed by building on rich qualitative data collected through 110 semistructured interviews conducted with local activists, community members, state officials and NGO practitioners who are actively involved in three different grassroots innovations. The interviews explored the dynamics of the initiation, operation, impact and sustainability of these grassroots innovations over time.

The model draws on three particular case studies that were tracked in Egypt over ten years. The first case study was in Manshiet Nasser, one of Cairo's largest slum areas, in which grassroots initiatives sought to address environmental, health and educational challenges faced by slum dwellers. The second case study was in Tafahna Al Ashraf village in the Deltra region where with the help of a local leader - the community succeeded in establishing a number of educational institutions from nursery to university through self-help (Ibrahim, 2013a). The third case study involves women groups in Upper Egypt who fight the practice of female genital mutilation (FGM) in rural villages in Menia. More recently, to assess the applicability of the model in different contexts, it has been applied on the community empowerment programme of Tostan, an international NGO that operates in six West African countries. Through 40 interviews and 6 focus groups conducted with community members, NGO staff and local state officials, the 3C-processes and their long-term impact on individual and communal wellbeing were examined. Adopting a grounded theory approach, the model is thus an inductive one that has been arrived at through comparative empirical analyses in different contexts. The model thus stresses the primacy of conscientization, conciliation and collaboration as integral 3C-processes to initiate, support and sustain grassroots innovations in practice. The following sections explain these processes and the factors affecting them.

\section{Conscientization}

The 3C-model presents conscientization as an essential condition for sustainable social innovations at the grassroots. This is mainly because the individual is the building block and the starting point of any social change. The model therefore starts with the articulation of individuals' values, aspirations and wellbeing goals in order to assess their ability to achieve these goals. Social innovation is closely linked to changes in values, social norms and local cultures (Murray et al., 2010) and can activate certain norms that encourage pro-social behaviour (Schwartz and Howard, 1981). It is therefore essential to study carefully local norms, social values and cultural practices, and to understand how people cognitively perceive their daily lives (Gonzalez and Healey, 2005). Sometimes, however, the implementation of social innovations can lead to a "fundamental clash of values, ideas and practices" (Seyfang and Haxeltine, 2012, p.384). To address this problem, the proposed model emphasizes the role of the conscientization process in articulating these norms and cognitive frames in order to induce positive behavioural changes. The question therefore is: How can the conscientization process support individuals to act as agents of change?

An agent is someone who initiates courses of action to achieve goals in accordance with his/her own values (Davis, 2004). Individuals who are agents "have diverse valued goals and commitments on behalf both of themselves and of their society" (Alkire, 2005a, 125). For an 
individual to become an agent, s/he needs to start thinking critically about his/her life. $\mathrm{S} /$ he needs to reflect critically about his/her current status, perceive and aspire for better living conditions and decide and plan an action to bring about this aspired change. The three stages 'reflection perception - action' constitute the conscientization process. Freire (1972, p.51 [emphasis added]) defines conscientization as "the process in which men, not as recipients, but as knowing subjects, achieve a deepening awareness both of the socio-cultural reality which shapes their lives and of their capacity to transform that reality". This process of self-scrutinizing and critical consciousness is therefore the starting point of social innovation at the grassroots. It enables individuals to think critically about their problems and then to actively engage in pursuing solutions to address them (Freire, 2000).

While not easy, awakening this critical consciousness is essential for the initiation and sustainability of grassroots innovations. That is why many NGOs start their community empowerment programmes with conscientization activities. According to Rowlands (1997, p.24), "the strategies identified for this approach revolve around the training of change agents (from within or outside the community); building women's groups; developing critical consciousness through dialogues, discussion and analysis, about structures of inequality and other problems raised by women; and enabling women to acquire new information and skills". These practices are well documented in various case studies where NGOs use audio and visual aids and exposure visits (Ziegler, 2013); human rights classes (Gillespie and Melching, 2010; Easton et al, 2003) and advocacy campaigns (Ibrahim, 2014) to induce positive changes in individual and communal behavior. The aim of these activities is to enhance the 'power from within' in order to empower local communities to lead their desired social change (Kabeer, 1994) and to support intrinsic empowerment (Pick and Sirkin, 2010).

Rowlands (1997, p.13) defines power from within as "the spiritual strength and uniqueness that resides in each one of us and makes us truly human. Its basis is self acceptance and self-respect". Whilst it is true that change can be induced through top-down policies or can happen through evolutionary accidents, however, the focus of the model, is on change from within because true power cannot be bestowed: it comes from within (Taliaferro, 1991). The power from within is enhanced when individuals believe in their abilities to change their lives; when they are able to challenge repressive household relations, and when they can rebuild their self-confidence and learn how they can induce positive changes in their own lives and in that of their communities. Social innovations can thus play an important role in unfolding this power from within, thereby helping individuals to act as agents of social change.

The dynamics and sustainability of the conscientization depend on a number of personal and contextual factors. First, they are affected by the individuals' personal traits such as self-confidence, educational level, profession and social status as well as the individuals' willingness to improve their lives. Second, the capacity to aspire is also crucial for the conscientization process. The 'capacity to aspire' is "how a group ... succeed[s] in reducing the costs of developing a culture of aspirations by collectively envisioning their future, and their capacity to shape this future, through influencing other groups, the government and other factors in their physical and social environment" (Appadurai, 2004, 64-65). This capacity, however, might sometimes be compromised through adaptive preferences when individuals adjust their "aspirations to feasible possibilities" (Elster, 1982, p.219). This adaptation is the third factor that can render the conscientization process more difficult. This is mainly because individuals would have had to "come to terms with their deprivation because of the sheer necessity of survival and they may, as a result, lack the courage to demand any radical change, and may even adjust their desires and expectations to what they unambitiously see as feasible" (Sen, 1999, p. 63). Adaptation can also create a 'false consciousness' that encourages individuals to accept different forms of inequalities, 
e.g. those based on class or gender (Qizilbash, 2012). Recent work (Clark, 2012) has shown, however, that individuals are less likely to adapt their aspirations or restrict them; especially if their individual and collective agency is supported. The role of the conscientization process is therefore crucial not only for awakening the critical consciousness of individuals and communities to aspire and thrive for better lives; but also to equip them with the necessary skills and training to achieve these lives.

Contextual factors, such as unequal power relations at the household and communal levels, can also constrain the conscientization process. These unequal relations affect the individual's selfconfidence, esp. among women, and can thus restrict their ability and willingness to change their lives. This constraining factor can be addressed through the conscientization process by emphasizing the importance of role models (Ray, 2006), introducing new forms of education and knowledge (e.g. on equal rights and responsibilities) and gradually promoting a culture of dialogue in households and communal spaces. Promoting social innovation at the grassroots thus needs to start with the conscientization process to help individuals to think critically about their lives, to gain more self-confidence and to challenge these unequal power relations. How this is done depends on each context; missing the whole conscientization process and starting grassroots innovations without having 'awakened' this critical consciousness jeopardizes the success of these innovations and limits their long term impact and sustainability. Conscientization is also important for the conciliation process in order to enable individuals to reconcile their self-interests with communal goals - as discussed in the next section.

\section{Conciliation}

Social innovation is not only about meeting social needs, but also about creating new social relations, social networks and collaborations (Caulier-Grice et al. 2012, Borzaga and Bodini, 2014). Networks are crucial enablers for new social practices and innovations (Cunha et al, 2015; Seyfang and Smith, 2007). As explained earlier, by acting individually community members are mostly unable to address the existing structural inequalities and social problems in their respective communities. That is why they need to act collectively. Conciliation among community members is therefore crucial to build on and enrich existing social capital for sustainable social innovations at the grassroots. The question, however, is how can individuals reconcile their own self-interests with communal goals?

To reconcile individual and communal goals through the conciliation process, a number of factors need to be addressed. First, a communal vision needs to be created through consensusbuilding while taking account of the multiplicity of communal needs; especially those of marginalised groups. The creation of a communal vision can happen via local deliberative processes that reconcile individual and communal wellbeing goals. Schapke and Rauschmayer (2014), for example, provide a useful analysis explaining how individual and collective interests can be reconciled. Using the case study of watershed development in India, Ziegler (2013) also explains how a 'social agreement' can arise in which different actors agree to cooperate, thereby creating new spaces for capability creation. This positive 'social agreement' was also reached in Tafahna Al Ashraf village in Egypt, where local communities pursued a communal vision or 'social agreement' to have education in their village 'from nursery to university'. When they established educational institutions through grassroots initiatives individuals benefited by educating their children, while at the same time pursuing a common good. This is how, through the conciliation process, a communal vision can be created at the same time as individual and communal goals are reconciled. 
A second core factor in the conciliation process is public deliberation and inclusive decision-making. Pelenc et al (2013, p.88) stress the "role of public discussion and social interactions in the emergence of shared values and commitments. Indeed, social interactions such as group discussions, community meetings or informal conversations, and so forth, are the means through which people can reveal to others his/her own representation of what wellbeing is". These deliberative spaces also provide agents with the opportunity to share and contest their diverse perceptions of the 'common good' (Pelenc et al, 2015). This process of deliberation and public reasoning was also emphasized by Sen (2002a) and Dreze and Sen (2002, p.368), who argued for the "possibility of achieving wider changes in social norms through local action". These deliberative processes, however, need to be institutionalised to ensure their sustainability and inclusivity. This can be done through village development committees (Ziegler, 2013), community management committees (Gillespie and Melching, 2010; Easton et al, 2003) or communal groups (Ibrahim, 2014). Participation in these local institutions needs to be voluntary, inclusive and transparent to enhance communal ownership of social innovation processes and to ensure that decision-making processes are not captured by already powerful social groups.

Third, for the conciliation process to succeed, a sense of communal responsibility needs to be nurtured. Responsibility is important for enhancing the individuals' social obligations and for balancing their wellbeing and agency achievements (Sen, 2008; 2004; 1985). Individuals need to be responsible "not only ex-post (i.e. once freedom has been exercised), but also ex-ante, by the capacity to exercise self-constraint on a voluntary basis in order to satisfy one's obligations towards others" (Ballet et al., 2007, 185[emphasis in original]). The voluntarism and ex-ante responsibility are crucial for the conciliation process. Grassroots innovations generate new collective capabilities; however community members do not necessarily equally benefit from these new capabilities. Adopting this wider concept of voluntarism is therefore essential for community members to see the benefits of their participation, i.e. their agency achievements, beyond their own wellbeing concerns. There are a number of ways through which one can nurture this feeling of voluntarism, such as enhancing the individuals' sense of belonging to their community, fostering inclusive decision-making processes, and solving existing communal conflicts as well as creating open spaces for communal participation.

By arguing for the importance of the conciliation process at the collective level, this paper does not deny the existence of various constraining factors that can obstruct this process. Deprived communities are highly disadvantaged in the formation of collectivities and groups given their limited access to resources, political voice and the unequal power relations in these communities (Thorp et al., 2005; Heyer, et al, 2002; Stewart, 2005). Group membership can even sometimes not only perpetuate poverty traps, but also reinforce existing structural inequalities; rather than helping individuals to overcome them (Durlauf, 2006). These constraining factors can be addressed through enhanced self-awareness, conscientization and public deliberation that canhelp communities to recognize their inherent collective strengths and the role their organizations can play in improving their lives (Freire, 1970; Esman and Uphoff, 1984; Krishna et al. (1997). The level of existing social capital (Putnam, 1993; 2000; Mair and Marti, 2006) and the role of local leaders/innovators (their personality, leadership skills, passion and vision) can all play a role in affecting the conciliation process. This, for example, was the case in Tafahna Al Ashraf village, where the local leader, Haj Salah Ateya, played an effective role in initiating and sustaining social innovation processes in the village (Ibrahim, 2013a). If, in contrast, local leaders are divisive and exclusionary, this can pose yet another constraining factor to the conciliation process. Thus, the reconciliation of communal and individuals' interests is not easy but not impossible. The potential benefits that can accrue to communities from the conciliation process can be important catalysts to help them overcome the various social, economic and political constraints affecting this process. If the conciliation process fails, this might lead to 
confrontation and conflict and so disrupt the process of social innovation at the grassroots - as will be discussed later in this article. To maximize the benefits from social innovation processes, local communities might also decide to partner with other actors through the collaboration process.

\section{Collaboration}

To sustain social innovations at the grassroots, local communities need to collaborate with other actors, such as the state, donor agencies and civil society organizations. Collaboration is important for two main reasons. First, it is essential for promoting local institutional reforms. Reviewing different theories of institutional change (Kingston and Caballero, 2009; North, 1990; 2005; Ostrom; 2005), the proposed 3C-model adopts Alston's (1996, p.26-27) definition of institutional change arguing that "institutional change results from the bargaining actions of demanders and suppliers". Second, the exercise of individual and collective agency alone (through conscientization and conciliation processes) is not enough for sustaining social innovations at the grassroots. Local communities need to challenge the unequal power relations between them and other development actors. Collaborations between grassroots actors (Leach et.al., 2012) is therefore essential to induce institutional change and to enhance the bargaining power of local communities vis-à-vis other actors.

Collaboration is not always straightforward and a number of factors can affect its success. For example, local communities might find difficulties in collaborating with local NGOs, if the latter mainly respond to donor-driven development agendas. Thornton et al. (2000) point out this tension in the role of NGOs as service providers and as facilitators. Some NGOs can be even heavily involved in politics, thus reproducing - rather than challenging - clientelistic relations in local communities (Devine, 2006). In this case, there is an urgent need to 'repair civil society failure' and to enhance their roles in coordination and cooperation (Mansuri and Rao, 2012). Ideally, NGOs need to play an effective role in "building the critical consciousness and collective capacity of poor men and women to lead the struggle for a more democratic society" (Kabeer and Sulaiman, 2015, p. 63). NGOs need to play the role of the "intermediary to accelerate the pace of the creation of GROs, provide them with assistance as they expand, and foster links between them" (Edwards and Hulme, 1992, p.84) and to act as "catalysts for institutional and policy change" (Korten, 1987, p. 145). For NGOs to play this facilitating role, they also need to coordinate their development work more effectively. This is how collaboration between local communities and NGOs can be based on the supportive and facilitative role that NGOs can play in initiating and supporting grassroots innovations.

For grassroots innovations to induce sustainable social change, local communities also need to collaborate with the state as this change "is embedded in the larger structure of the state and its coercive power" (Zielger, 2013, p.12). The relationship between the state and local communities is affected by the political context. For example, authoritarian regimes can affect all three Cprocesses by restricting the spaces for deliberation and controlling local institutions. The state can even reinforce existing social hierarchies based on class, gender and caste (Ziegler, 2013; Kale, 2011). Effective accountability channels and decentralized decision-making processes are therefore necessary to promote effective partnerships between local communities and the state. Collaborating with the state is also essential for scaling-up grassroots innovations and integrating them within local and national development policies. Given the difficulties that communities face in partnering with the state, Miltin (2013) points out the important role of alliance-building. She explains how local communities link up with professionals to establish partnerships with the state and adds that in order "to legitimize and/or resource their struggles, these groups make alliances with a range of professionalized support agencies... Such alliances appear necessary for a 
grassroots voice to be heard and recognized... [but] the difference in social status self-evidently puts local groups and social movements at risk of being undermined and displaced" (Mitlin, 2013, p.483). This, however, does not mean that meaningful collaboration between local communities and professionals cannot exist. The example of SDI (Shack/Slum Dweller International) (Patel et.al, 2001) shows how through federation activities, communal meetings and regular consultations, local communities are able to discuss solutions with professionals and state officials.

Other factors, such as funding availability and the nature of partnerships, can also affect the success of the collaboration process. Whilst communities need funding to undertake conscientization activities and to pursue their communal vision, getting funds from other actors can sometimes create dependency, distort the 'voluntary' nature of grassroots innovations and cause communal divisions - thus jeopardizing all 3C-processes. Furthermore, for effective collaborations, development actors need to perceive local communities as equal partners and acknowledge their positive role in enhancing development outcomes (Gaventa and Barrett, 2010). Finally, different actors operate within different timeframes. For collaboration to succeed, it is therefore important that "we conceive change of the social forces in the correct timeframe, [and that] we expect social innovation processes to alter the context in which they have been born" (Chiappero-Martinetti and Von Jacobi, 2015, p.4). Effective collaboration therefore requires actors to reconcile their visions of social change and their perceived timeframes in which they seek to achieve this change.

This section explained the dynamics of the conscientization, conciliation and collaboration processes and the factors affecting them. The next section presents the limitations of the 3C model and explains how the impact of grassroots innovations can be assessed.

\section{The Limitations of the 3C-Model}

Having presented the model and its 3C-processes, it is important to also explain its limitations. These limitations can be summed up in terms of another set of 3C processes, namely: confrontation, cooptation and capture. This section also emphasizes the role of context as the 'invisible' $\mathrm{C}$ in the model.

Confrontation and Conflict are not unlikely either among community members in multi-ethnic societies or between the state officials and local communities; esp. when the former fail to address the needs of the latter. Social innovation processes can by nature be contested processes as they involve a power struggle between agents (Beckert, 2010; Chiappero-Martinetti and Von Jacobi, 2015). Ziegler (2010) provides a useful account of how 'the social' can be complex in the context of value diversity and conflict of interest. Confrontation and conflict can therefore occur when communal priorities change or when the state fails to adapt its policies to meet those priorities. Griewald and Rauschmayer (2014) analyze such a conflict between collective actors and demonstrate how cooperation can fail and lead to confrontation. Pelenc et al (2015, p. 228) also show how "public discussion and social interactions do not automatically lead to the convergence of motivations ... Sometimes differences arise (divergence) between individuals during the confrontation of their values, interest, motivations and sense of responsibility" thus leading to conflict (Cleaver, 1999). To avoid conflict, Griewald and Rauschmayer (2014) and Pelenc et al (2015) identified a number of 'conversion factors' that affect the nature and outcome of this conflict, namely existing legal frameworks, political context as well as the actors' values, characteristics and adopted strategies. Deliberative processes and accountability mechanisms are also important for articulating communal voices and for resolving potential conflicts of interests before they lead to confrontation. 
Cooptation is yet another crucial process that can interrupt social innovations at the grassroots. It is similar to clientization which "reduces grassroots organizations .. to clients of the state apparatus, because either their critical capacities are blunted by benefits received from the state, or their activities are reduced to delivering social services for the state (Fowerake, 2001, p.26) Cooptation is thus a process in which "clientelist practices can reassert themselves at the expense of community interests" (Fowerake, 2001, p. 24). Cooptation of local leaders and active community members can distort the collective spirit of social innovations and disrupt the conciliation process. The danger of cooptation is particularly evident in collaborative partnerships with other actors, especially the state. Growing state control and its distortion of bottom-up processes through cooptation is a serious threat to all $3 \mathrm{C}$ processes. Whilst development actors (such as the state, NGOs and donor agencies) are encouraged to support the 3C processes, their collaboration, however, needs to be based on transparency and mutual accountability to avoid cooptation. To limit cooptation, it is also important that communities openly discuss what they want to get out of their collaborative partnerships with other actors and to clarify the responsibilities of each actor in social innovation processes.

Capture is also another important factor that can negatively affect grassroots innovations as it creates 'winners and losers' and can lead to unequal distribution of benefits and capabilities generated by these social innovations. Elite capture is particularly threatening in stratified societies with multiple ethnic and religious groups, because elites tend to 'divide and rule' to maintain their control over local communities and use this control for economic and political patronage. In addition to elite capture, institutional capture and path dependence are further limitations on the 3C processes. Pel and Bauler (2014, p.25) point out that "institutionalisation could also be a foreboding of transformative impulses being channelled, encapsulated, domesticated and eventually stifled by the very institutional structures they were to change". It is therefore important to safeguard the benefits of social innovation processes against elite and institutional capture in order to enhance the success, sustainability and scalability of grassroots innovations.

Context plays a crucial role not only in enabling or constraining social innovations, but also in affecting the direction of social change and how (and whether) it occurs. Whilst 'Context' can be in fact the 'invisible $C^{\prime}$ in the proposed model, the aim of this analysis is to explain how context matters and to identify the contextual factors that can hinder or enable the $3 \mathrm{C}$ processes. In addition to the aforementioned limitations, there are a number of contextual factors that affect social innovations at the grassroots. Mendes et al (2012), for example, differentiate between structural and agency barriers. The former refer to factors affecting the uncertainty and complexity of social processes, such as insufficient information, path dependence (Seyfang and Smith, 2007), limited funding (Caulier-Grice et al., 2012), and lack of data and measurement (Mendes et al., 2012). The latter are linked to the characteristics of individuals or organisations involved in social innovation processes. Exploring the factors that affect capability innovation, Ziegler et al (2013) also distinguish between direct and indirect conversion factors. The former relate to the actors involved in the social innovation process; while the latter refers to the (formal and informal) institutional setting in which they act. Through comparative case study analysis of urban development in Kenya, they show how indirect contextual factors can also play a crucial role in affecting the success or failure of social innovations. Other important factors to take into account include the size of the community, its rural/urban setting, the availability of financial resources, the communal experience with collective action and their previous histories of mobilization in the past. The role of contextual factors in affecting social innovation thus cannot be neglected. These factors need to be well-articulated and addressed in order to promote and sustain social innovations at the grassroots. The next section explains how the impact of these innovations can be assessed by focusing on their success, sustainability and scalability. 


\section{Assessing Grassroots Innovations - The 3Ss}

\section{Success}

The literature on success and success criteria is diverse in the development literature. Some scholars have sought to explore the impact of poverty reduction initiatives (Krishna et. al, 1997; Uphoff et.al, 1998), others sought to examine the organisational characteristics of 'successful' development agencies (Korten, 1980; Paul, 1982) or to link social entrepreneurship to societal transformations (Alvord et.al, 2004; Zahra et al, 2009). In his work on social movements, Andrews (2001, p. 72 ) argues that "success implies the attainment of specific, widely shared goals, but the goals of most social movements are contested by participants and observers". To address this problem, Mair and Marti (2006, p.41) propose that "instead of focusing on the success or failure of a program or initiative, it would be better to start measuring degrees of success or failure, always bearing in mind the intended and unintended consequences of the initiative". It is therefore important to note that there is not a 'single' notion of success or a clear line between success and failure for assessing grassroots innovations. Having identified the importance of success, it is essential to acknowledge that "innovation must [also] involve failure" (Mulgan, 2006, p.156). Who defines success and how it is defined are therefore important questions that need to be addressed.

The success of most development projects is conventionally assessed through outcomes and performance indicators. The 'value for money' rhetoric dominates development practice. However, when assessing grassroots-led processes through this narrow lens it not surprising that 'assessors' might find only minimal changes in the respective communities. This is mainly because change - in this context - is purely measured by outcomes and hence the dynamics of social innovation processes are overlooked. Here "the real problem may not be the measurement per se, but how the measures may be used to 'quantify' the performance and impact ... it [is] very difficult ... to quantify socio-economic, environmental and social effects" (Mair and Marti, 2006, p. 42). The success of social innovations should therefore be assessed based on their ability to empower local communities to have the capacity to act (Moulaert et al., 2005), to add social value beyond measurement and quantification (Mair and Marti, 2006), to be resilient to adverse conditions, and to sustain this change over the long-term (Caulier-Grice et al., 2012; Mendes et al, 2012; Lodemann and Ziegler, 2105). Success of social innovations also depends on their ability to adapt to complex realities and to address the root causes of social problems and so go "beyond the superficial 'symptomatic' level" (Chalmers, 2012, p.22). To define success, it is important to articulate local communal perceptions of success. These localised notions, however, might turn out to be problematic given the multiplicity of communal views. They can also differ from the standard performance indicators, theories of change or log frames used by donors and other development actors to assess success.

Success is this model is not defined by outcomes, but rather by processes. The emphasis here is on process freedoms, rather than opportunity freedoms (Sen, 2002b). "Process freedoms are related to persons' ability to exert agency in ways that further their conception of the good" (Alkire, 2005b, p.3). It is the process that counts, not only the outcomes or opportunities per se. If success is perceived from this broader process-based perspective, positive incremental change can be better captured and assessed. Since the model is circular, there is no point in time where one can identify that a particular process is successful or not. This is mainly as the successes of the $3 \mathrm{C}$ processes are highly inter-dependent and mutually-reinforcing. The $3 \mathrm{C}$ processes and the capabilities they generate are highly inter-connected as they mostly complement and strengthen each other (Ziegler, 2010). Success thus needs to account for the constant interaction between the social innovation processes and the context in which they are embedded and needs to 
consider the impact of this interaction on human capabilities - both at the individual and collective levels.

\section{Sustainability}

Sustainability is considered one of the criteria for success and is essential for assessing the impact of social innovations at the grassroots. Sustainability can be defined in different ways. Exploring the sustainability of grassroots innovations, Seyfang and Smith (2007) differentiate between the direct environmental benefits of these grassroots initiatives and their wider impact on the quality of life of local communities. This model adopts the latter definition arguing that sustainability of social innovations needs to be assessed based on the effect they have on individual and communal lives. Phills et al. (2008, p.37) adds that "by sustainable we mean solutions that are environmentally as well as organizationally sustainable - those that can continue to work over a long period of time". Sustainability is therefore not only linked to the impact of social innovations on quality of life; but also to the long-term impact of these innovations. The timeframe which is used to assess sustainability is problematic; especially as different development actors operate within diverse timeframes. Whilst communities seek to achieve positive changes in their lives on a long-term basis, the state and other actors might be more interested in shorter-term immediate outcomes to demonstrate the impact of their development work. The 3C model adopts a people-centred view of sustainability as local communities "have experience and knowledge about what works in their localities, and what matters to local people. They can be well placed to present sustainability issues in ways more meaningful, personal and directly relevant" (Seyfang and Smith, 2007, p. 593-594).

Financial sustainability is another important aspect that affects the continuity and durability of social innovations at the grassroots. This is mainly because "funding constraints inhibit experimentation and punish failure by withdrawal of resources" (Seyfang and Smith, 2007, p. 597). Deprived communities also face a number of structural constraints and market failures to generate and sustain their own funds for grassroots innovations. Even when these funds are secured or locally generated, they still remain subject to elite capture and corruption in the absence of transparent and effective accountability mechanisms among and between different actors. To ensure that the sustainability of grassroots innovations is enhanced, it is important to account for the long-term nature of social change and to generate sufficient resources that can sustain this change and foster its positive impact on the quality of life of local communities.

\section{Scaling-up}

One way to sustain grassroots innovations is to scale them up. Grassroots initiatives, however, are mostly viewed as localised solutions that are hard to scale-up (Edwards and Hulme, 1992). Scholars against scaling-up argue that social innovation initiatives are embedded in their context and hence might be difficult to implement across new geographic and communal borders (Mair and Marti, 2006). Others view scaling-up as integral to the process of social innovation for these innovations to have an effective impact on the social problems they seek to address. Borzaga and Bodini (2014), for example, argue that "social innovation should not consist only of an isolated incident but should be replicable and have the potential to scale up in order to have a significant impact ... Consequently, more attention needs to be paid to the scalability of the innovation in addition to its novelty" (Borzaga and Bodini, 2014, p.415). Scalability is thus integral to successful and sustainable grassroots innovations. Scale does matter. From a resilience perspective, different scales can produce different outcomes as change in one level might lead to stability in another (Lodemann and Ziegler, 2015). From a human development perspective, scaling involves capabilities improvements or a 'climbing up of the ladder' (Ziegler et al, 2013). 
Scaling-up, however, is not straightforward as "only a small minority of social entrepreneurs create new models that can then be scaled up, and that process of scaling up often involves governments and larger businesses" (Mulgan et al, 2007, p. 45). Seyfang and Haxeltine (2012) differentiate between various ways in which innovative ideas and initiatives can be diffused, such as through replication, scaling up and translation. Replication refers to the application of the social innovation in a new context (mostly a new geographic area) (Seyfang and Haxeltine, 2012). Ziegler et al (2013) also differentiate between lab and family strategies for scaling-up social innovations; the former is a mere replication and reproduction of the initiative in a new context; while the latter accounts for contextual factors and adapts the initiative to the new environment. They explain that 'to scale' one can increase production, collaborate with new partners or replicate the initiative. Rejecting replication, Ziegler (2013, p.12) argues that "it would be a mistake to think of scaling as the 'replication' of a model in the sense of a copy", which is why he stresses the need to adapt social innovations to their respective contexts. Our model adopts the latter view of scaling-up as an adaptive strategy to account for contextual factors that affect social innovation processes when implementing it in new locations or domains. The question is therefore how can grassroots innovations be scaled-up - in light of the proposed 3C-model?

The model embeds a scaling-up potential in its three components. First, many conscientization activities are replicable at different scales. Individuals can act as agents of change by raising the awareness of other community members, e.g. as was the case with the fight against FGM in rural Egypt (Ibrahim, 2014). Second, through conciliation, a communal vision is created that allows neighbouring communities to see the benefits of social innovation and draw their own lessons from it to induce positive social change in their respective areas. The success of social innovation in Tafahna Al Ashraf village in Egypt, for example, set in train a multiplier effect that led to the scaling-out of social innovations to neighbouring villages (Ibrahim, 2013a). Finally, collaboration is important to enhance the scalability of grassroots innovations. This is mainly because "smallscale initiatives can reproduce elsewhere by ensuring groups are well connected regionally and nationally" (Seyfang and Smith, 2007, 596). Referring to micro-credit and fair trade as successful scalable social innovations, Cunha et al (2015) explain how 'micro-experiments' at the communal level can become universal and have real impact on communities in the Global South. To do so, it is important for grassroots innovations to find 'champions' beyond their immediate context and to challenge the power of those who benefit from the status quo (Cunha et al, 2015). To scale-up social innovations, it is also essential to build networks among and between different actors (Seyfang and Haxeltine, 2012); otherwise "social innovations are stillborn and ... many social entrepreneurs are frustrated" (Mulgan et al., 2007). For these networks to be effective, it is important to engage local institutions, promote co-management, establish decentralised decisionmaking and allow power sharing; especially at the local level (Jones, 2011). Through effective partnerships and careful scaling-up and scaling-out strategies, grassroots innovations can expand their impact to new contexts.

\section{Conclusion}

In conclusion, this article presented a new model to explain how social innovations at the grassroots can be initiated, supported and sustained. The model emphasized the centrality of three processes: (1) conscientization at the individual level, (2) conciliation at the collective level, and (3) collaboration at the institutional level. It explored the dynamics of each of these three Cprocesses stressing the importance of individual behavioural changes, collective agency and local institutional reforms for the success, sustainability and scalability of grassroots innovations. The model focused on the process of change itself viewing the $3 \mathrm{C}$ processes as means and ends for social change. By focusing on these three C-processes, the model presented a clearer framework for conceptualising, operationalising and understanding the dynamics of social innovation processes 
at the grassroots. Adopting the Capability Approach as an evaluative framework for the model, the paper stressed the role of grassroots innovations in supporting collective agency, generating new collective capabilities and challenging unequal power relations within local communities and among development actors. The model sought to explore the interactive relationship between agency and structure and to show how grassroots innovations can promote 'real' empowerment and participation by supporting power from within (through conscientization); power with (through conciliation) and power to and power over (through collaboration). The paper explained the importance of conscientization for enhancing the capacity to aspire of local communities and for inducing positive changes in social norms to support grassroots innovations. It also explored the dynamics of the conciliation process which is essential to reconcile individuals' self-interests with communal goals. The paper also explained the importance of building effective collaborative partnerships between local communities and other development actors and examined the difficulties they face in building and sustaining these partnerships. The model's limitations were also discussed illustrating how the failure of the 3C-processes can lead to conflict, confrontation, capture and cooptation. Finally, the paper explored three evaluative aspects of grassroots-led development that can be used to assess social innovations at the grassroots, namely through: success, sustainability and scalability. It demonstrated the difficulty of defining each of these criteria and explained their importance for grassroots innovations. The strength of the model lies in its clarity, its focus on processes (rather than outcomes) and its emphasis on the interactive nature of the $3 \mathrm{C}$-processes and the contextual factors affecting them.

As for its policy relevance, the model emphasizes the central role that grassroots innovations can play in initiating and supporting social change and explains how this role can be supported and enhanced by different development actors. It builds on a growing international interest in social innovations emphasizing their role, for example, in reaching the new SDGs (Sustainable Development Goals). Leach et al. (2012, p.11) explain how these "local initiatives often flourished and drew on people's own, vibrant forms of knowledge, technology and experimentation, but ... they remained at the margins". Acknowledging the complexity of grassroots-led processes, the model identifies three specific processes (conscientization, conciliation and collaboration) that can help to enhance the impact of grassroots innovations. The model also provides a useful framework for assessing these innovations by focusing on their success, sustainability and scalability. By focusing on 'what works', the model not only presents a useful conceptual framework for understanding the dynamics of social innovation processes for academics, it also constitutes a useful guide for practitioners when it comes to designing, planning, implementing and supporting sustainable, successful and scalable social innovations at the grassroots. 


\section{References}

Andrews, K. T. (2001) 'Social movements and policy implementation: The Mississippi civil rights movement and the war on poverty, 1965 to 1971', American Sociological Review, pp. 71-95.

Alkire, S. (2005a) 'Why the Capability Approach', Joumal of Human Development, 6 (1), pp. 115-133.

Alkire, S. (2005b) 'Measuring the Freedom Aspects of Capabilities'. Mimeo. Accessed online: 3 Oct 2015, https://www.aeaweb.org/assa/2005/0107 1430 0104.pdf

Alkire, S. (2008) Using the capability approach: prospective and evaluative analyses, in S. Alkire, S., F. Comim, M. Qizilbash (eds.) The Capability Approach: Concepts, Measures and Application. Cambridge University Press, Cambridge, pp. 26-50.

Alsop, R. \& N. Heinsohn (2005) Measuring Empowerment in Practice: Structuring Analysis and Framing Indicators, Policy Research Working Paper, Washington DC: World Bank.

Alsop, R., Bertelsen, M. \& Holland, J. (2006) Empowerment in Practice From Analysis to Implementation, Washington, DC: World Bank.

Alston, L. (1996), 'Empirical Work in Institutional Economics: An Overview', in L. Alston, T.

Eggertsson, and D. North (eds.), Empirical Studies in Institutional Change, Cambridge University Press, pp. 25-30.

Alvord, S., L.D. Brown and C.W. Letts (2004) 'Social Entrepreneurship and Societal Transformation: An Exploratory Study', The Journal of Applied Behavioural Science, 40 (3), pp. 260 282.

Appadurai, A. (2004) 'The Capacity to Aspire: Culture and the Terms of Recognition', in V. Rao and M. Walton (eds.), Culture and Public Action: A Cross-Disciplinary Dialogue in Development Policy. Stanford: Stanford University Press, pp. 59-84.

Ballet, J., J.L. Dubois, and F. R. Mahieu (2007) 'Responsibility for Each Other's Freedom: Agency as the Source of Collective Capability', Journal of Human Development, 8 (2), pp. 185-201.

Battilana, J. (2006) 'Agency and Institutions: the Enabling Role of Individuals' Social Position', Organization, 13 (5), pp. 653-676.

Battilana, J., B. Leca and E. Boxenbaum (2009) 'How Actors Change Institutions: Towards a Theory of Institutional Entrepreneurship', The Academy of Management Annals, 3 (1), pp. 65-107.

Beckert, J. (2010) 'How Do Fields Change? The Interrelations of Institutions, Networks, and Cognition in the Dynamics of Markets', Organization Studies, 31 (5), pp. 605-627.

Biggs, R., F. R. Westley and S. R. Carpenter (2010) Navigating the back loop: fostering social innovation and transformation in ecosystem management. Ecology and Society 15(2), pp. 9.

Bonifacio, M. (2014) 'Social Innovation: a novel policy stream or a policy compromise? An EU perspective', European Review, 22, pp. 145-169. 
Borzaga, C. and R. Bodini (2014) 'What to Make of Social Innovation? Towards a Framework for Policy Development', Social Policy and Society, 13, pp 411-421

Bourdieu, P. (1977) Outline of a Theory of Practice. Cambridge: Cambridge University Press.

Budd, C.H, C.W.M. Naastepad and C. van Beers (2015) 'Introduction', CRESSI Working Papers No. 1/ 2015; accessed online, 1 Sep 2016, http://www.sbs.ox.ac.uk/sites/default/files/researchprojects/CRESSI/docs/CRESSIWorkingPaper1D1.1Chp11Nov182014.pdf

Caulier-Grice, J., A. Davies, R. Patrick and W. Norman (2012) Defining social innovation. A deliverable of the project: "The theoretical, empirical and policy foundations for building social innovation in Europe” (TEPSIE), European Commission - 7th Framework Programme, Brussels: European Commission, DG Research.

Chalmers, D. (2012) Social innovation: An exploration of the barriers faced by innovating organisations in the social economy. Local Economy, 28(1), pp. 17-34.

Chambers, R. (1997) Whose Reality Counts? Putting the First Last. London: Intermediate Technology Publications.

Chambers, R. (1993) Challenging the Professions: Frontiers for Rural Development, London: Intermediate Technology Publications.

Chiappero-Martinetti, E. and N. von Jacobi (2015) 'How can Sen's 'Capabilities Approach' Contribute to Understanding the Role for Social Innovations for the Marginalized?', CRESSI Working Papers No.3/ 2015; accessed online, 7 Oct 2015: http://www.sbs.ox.ac.uk/sites/default/files/researchprojects/CRESSI/docs/CRESSI_Working_Paper_3_D1.1_Chp3_18Nov2014.pdf

Clark, D. (2012) Adaptation, Poverty and Development: The Dynamics of Subjective Well-Being. Basingstoke: Palgrave MacMillan.

Cleaver, F. (1999) 'Paradoxes of Participation: Questioning Participatory Approaches to Development'. Journal of International Development, 11, pp. 597-612.

Cleaver, F. (2007) 'Understanding Agency in Collective Action', Journal of Human Development, 8 (2), pp. 223-244.

Cooke B. and U. Kothari (2001) (eds.) Participation: the New Tyranny. London and New York: Zed Books.

Cornwall, A. (2002) Making Spaces, Changing Places: Situating Participation in Development, IDS Working Paper 170, Brighton: IDS.

Cornwall, A. (2006) (Ed.) Historical perspectives on participation in development, Commonwealth and Comparative Politics, 11:1, 62-83.

Cornwall, A. (2008) 'Unpacking 'Participation': models, meanings and practices, Community

Development Journal, 43 (3), July 2008, pp. $269-283$. 
Cornwall, A. and K. Brock (2005) 'What Do Buzzwords Do for Development Policy? A Critical Look at 'Participation', 'Empowerment' and 'Poverty Reduction', Third World Quarterly, 26 (7), pp. 1043-1060.

Cunha, J., P. Benneworth, \& P. Oliveira (2015) 'Social Entrepreneurship and Social Innovation: A Conceptual Distinction', in Farinha et al (eds.) Handbook of Research on Global Competitive Advantage through Innovation and Entrepreneurship, IGI Global, pp. 616-639).

Davis, J. (2004) 'Identity and Commitment: Sen's Conception of the Individual', Tinbergen Institute Discussion Paper, no. 055/2, Amsterdam: University of Amsterdam Press.

Dawson, P. and L. Daniel (2010) 'Understanding social innovation: A provisional framework', International Journal of Technology Management, 51(1), pp. 9-21.

Devine, J. (2006) NGOs, Politics and Grassroots Mobilization: Evidence from Bangladesh, Journal of South Asian Development 1 (1), pp. 78-99.

Douglas, M. (1987) How Institutions Think. London: Routledge.

Drèze, J. and Sen, A. (2002) India: Development and Participation. Oxford: Oxford University Press.

Durlauf, S.N. (2006) Groups, Social Influences and Inequality: A Membership Theory Perspective on Poverty Traps, in Poverty Traps, S. Bowles, S. Durlauf, and K. Hoff (eds.) Princeton: Princeton University Press, pp. 141-175.

Easterly, W. (2006) The white man's burden: Why the West's efforts to aid the rest have done so much ill and so little good. Penguin Press, New York.

Easton, P., K. Monkman and R. Miles (2003) Social Policy from the Bottom up: Abandoning FGC in Sub-Saharan Africa, Development in Practice, 13 (5), (Nov., 2003), pp. 445-458.

Edwards, M. And D. Hulme (1992) Scaling-up NGO Impact on Development: Learning from Experience, Development in Practice, 2 (2), pp. 77-91.

Elster, J. (1982) 'Sour Grapes- Utilitarianism and the Genesis of Wants', in A. Sen and B. Williams (eds.) Utilitarianism and Beyond. Cambridge: Cambridge University Press.

Esman, M. and N. Uphoff (1984) Local Organizations: Intermediaries in Rural Development. Ithaca: Cornell University Press.

Evans, P. (2002) 'Collective Capabilities, Culture and Amartya Sen's Development as Freedom' Studies in Comparative International Development, 37(2), pp. 54-60.

Fowerake, J. (2001) 'Grassroots Movements, Political Activism and Social Development in Latin America A Comparison of Chile and Brazil', UNRISD Civil Society and Social Movements Programme paper no. 4, accessed online: http://www.unrisd.org/80256B3C005BCCF9/httpNetITFramePDF?ReadForm\&parentunid=D C22E12D3F6AB4EB80256B5E004D27A8\&parentdoctype $=$ paper\&netitpath=80256B3C005BC CF9/(httpAuxPages)/DC22E12D3F6AB4EB80256B5E004D27A8/\$file/fowerake.pdf 
Freire, P. (1970) Pedagogy of the Oppressed. New York: Herder and Herder.

Freire, P. (1972) Cultural Action for Freedom. Middlesex: Penguin.

Freire, P. (2000) Education of Critical Consciousness. New York: Contimuum.

Friedland, R., and R.R. Alford (1991) 'Bringing society back in: symbols, practices, and institutional contradictions' in The New Institutionalism in Organizational Analysis. W. Powell and P.J. DiMaggio (eds), Chicago: University of Chicago Press, pp. 2320-2363.

Friedmann, J. (1992) Empowerment: The Politics of Alternative Development, Oxford: Blackwell.

Garud, R., C. Hardy and S. Maguire (2007) 'Institutional Entrepreneurship as Embedded Agency: An Introduction to the Special Issue', Organisation Studies, 28 (7), pp. 957-969.

Gaventa, J. (2006) 'Finding the Spaces for Change: A Power Analysis', IDS Bulletin, 37, pp. 23-33.

Gaventa, J. And G. Barrett (2010) So What Difference Does it Make? Mapping the Outcomes of Citizen Engagement, IDS working paper 347, accessed online: 4 Oct 2015, https://www.ids.ac.uk/files/dmfile/Wp347.pdf

Giddens, A. (1984) The Constitution of Society. Cambridge, MA: Polity Press.

Gillespie, D. and M. Melching (2010) The Transformative Power of Democracy and Human Rights in Nonformal Education: The Case of Tostan, Adult Education Quarterly, 60(5), pp. 477498.

Goldenberg, M., W. Kamoji, L. Orton, and M. Williamson (2009) Social Innovation in Canada: An Update, CPRN Research Report, Ottawa: Canadian Policy Research Networks, http://www.cprn.org/documents/51684_EN.pdf (accessed 1 Sep 2016).

Goldstein J, JK Hazy and J Silberstang (2010) A complexity science model of social innovation in social enterprise, Journal of Social Entrepreneurship 1(1), pp. 101-125.

González, S. and P. Healey (2005) 'A sociological institutionalist approach to the study of innovation in governance capacity', Urban Studies, 42(11), pp. 2055-2069.

Griewald, Y., and F. Rauschmayer (2014) Exploring an environmental conflict from a capability perspective, Ecolological Econonomics, 100, pp. 30-39.

Hamalainen TJ and R. Heiskala (2007) Social Innovations, Institutional Change, and Economic Performance: Making Sense of Structural Adjustment Processes in Industrial Sectors, Regions, and Societies. Cheltenham: Edward Elgar.

Heyer, J., Stewart, F. and Thorp, R. (2002) Group Behaviour and Development: Is Market Destroying Cooperation? Oxford: Oxford University Press.

Hickey, S. and G. Mohan (2004) 'Towards participation as transformation: critical themes and challenges' in S. Hickey and G. Mohan (eds.) Participation: From Tyranny to Transformation? Exploring New Approaches to Participation in Development. London and New York: Zed Books. 
Holm, P. (1995) 'The Dynamics of Institutionalization: Transformation Processes in Norwegian Fisheries', Administrative Science Quarterly, 40, pp. 398-422.

Holmes S. and P. Smart (2009) 'Exploring open innovation practice in firm-nonprofit engagements: A corporate social responsibility perspective', R\&D Management, 39(4), pp. 394409.

Howaldt, J. and M. Schwarz (2010) Social innovation: concepts, research fields and international trends. Dortmund: Report of ESF, EU, and Aachen University.

Ibrahim, S. (2006) 'From Individual to Collective Capabilities: the Capability Approach as a Conceptual Framework for Self-help', Journal of Human Development, 7 (3), pp. 398-416.

Ibrahim, S. (2008) Collective agency: wider freedoms and new capabilities through self help in Dubois, J.-L., A.-S., Brouillet, P. Bakhshi and S. Duray-Soundron (eds.), Repenser l'action collective: Une approche par les capabilités. l'Harmattan, Paris, pp. 61-81.

Ibrahim, S. (2013a) 'Unfolding the Developmental Potential of Islam' in H. Moksnes and M. Melin (Eds.) Faith in Civil Society: Religious Actors as Drivers of Change, Uppsala: Uppsala University Press, pp. 129-133.

Ibrahim, S. (2013b) Collective capabilities: what are they and why are they important? Maiyteree 22 , pp. 4-8.

Ibrahim, S. (2014) 'The Dynamics of Collective Agency in Practice: Women's Fight against FGM in Upper Egypt' in S. Ibrahim and M. Tiwari (Eds.) The Capability Approach: From Theory to Practice, Basingstoke: Palgrave MacMillan: pp. 52-72.

Ibrahim, S. and S. Alkire (2007) 'Agency and Empowerment: A Proposal for Internationally Comparable Indicators', Oxford Development Studies, 35:4, pp. 379-403.

Jones, H. (2011) Taking Responsibility for Complexity, ODI working paper no. 330, accessed online, 10 Oct 2015, http://www.odi.org/sites/odi.org.uk/files/odi-assets/publications-opinionfiles/6485.pdf

Kabeer, N. (1994) 'Empowerment from Below: Learning from the Grassroots' in Kabeer, N. Reversed Realities: Gender Hierarchies in Development Thought, London, Verso, pp. 223-263.

Kabeer, N. (2003) 'Making rights work for the poor: Nijera Kori and the construction of "collective capabilities" in rural Bangladesh', IDS working paper no. 200, accessed online: 7 Oct 2015, https://www.ids.ac.uk/files/wp200.pdf

Kabeer, N. And M. Sulaiman (2015) Assessing the Impact of Social Mobilization: Nijera Kori and the Construction of Collective Capabilities in Rural Bangladesh', Journal of Human Development and Capabilities, 16 (1), pp. 47-68.

Kale, E. (2011) Social Exclusion in watershed development: evidence from the indo-german watershed development project in Maharashtra, Law Environment and Development Journal, 7 (2), pp. $97-116$. 
Kingston, C. And G. Caballero (2009) 'Comparing theories of institutional change', Journal of Institutional Economics, 5, pp. 151-180.

Klein J-L, D-G Tremblay and DR Bussieres (2010) Social economy-based local initiatives and social innovation: A Montreal case study, International Journal of Technology Management 51(1), pp. 121-138.

Korten, D. (1980) 'Rural Organisation and rural development: A learning process approach', Public Administration Review, 40, pp. 480-511.

Korten, D. (1987) Third Generation NGO Strategies: A Key to People-Centered Development, World Development, 15, supplement, pp. 145-159.

Krishna, A., N. Uphoff and M.J. Esman (eds.) (1997) Reason for Hope: Instructive Experiences in Rural Development, West Hartford, CT: Kumarian.

Leach, M., J. Rockström, P. Raskin, I. Scoones, A. C. Stirling, A. Smith, J. Thompson, E. Millstone, A. Ely, E. Arond, C. Folke, and P. Olsson. (2012) 'Transforming innovation for sustainability', Ecology and Society 17(2): 11.

Lodemann, J. and R. Ziegler (2016) 'How Can Resilience Theory inform Social Innovation for the Marginalized', CRESSI Working Papers No. 6/ 2015; accessed online, 1 Sep 2016, http://www.sbs.ox.ac.uk/sites/default/files/research-

projects/CRESSI/docs/CRESSI_Working_Paper_6_D1.1_CHP_6_18Nov2014.pdf

Mair, J. and I. Marti (2006) 'Social entrepreneurship research: A source of explanation, prediction, and delight', Journal of world business, 41(1), pp. 36-44.

Mair, J. and I. Marti (2009) 'Entrepreneurship in and around institutional voids: A case study from Bangladesh', Journal of Business Venturing, 24 (5), pp. 419-435.

Mansuri, G. And V. Rao (2004) 'Community-based and -Driven Development: A Critical Review', World Bank Research Observer, 19 (1), pp. 1-39.

Mansuri, G. And V. Rao (2012) Localising Development: Does Participation Work. World Bank Research Policy Report. Washington, D.C.: World Bank. Accessed online: 10 Oct 2015; http://siteresources.worldbank.org/INTRES/Resources/469232-1321568702932/82737251352313091329/PRR Localizing Development full.pdf

Mendes, A.; A. Batista; L. Fernandes; P. Macedo; F. Pinto; L. Rebel; M. Ribeiro; R. Ribeiro; M. Sottomayor; M. Tavares; V. Verdelho (2012) Barriers to Social Innovation. A deliverable of the project: "The theoretical, empirical and policy foundations for building social innovation in Europe" (TEPSIE), European Commission - 7th Framework Programme, Brussels: European Commission, DG Research.

Mitlin, D. (2013) 'A Class Act: Professional Support to People's Organisations in Towns and Cities of the Global South', Environment and Urbanisation, 25 (2), pp. 483-499.

Moulaert, F. and J. Nussbaumer (2005) The social region: beyond the territorial dynamics of the learning economy, European Urban and Regional Studies, 12(1), pp. 45-64. 
Moulaert, F., F. Martinelli, E. Swyngedouw and S. Gonzalez (2005). Towards alternative model (s) of local innovation. Urban studies, 42(11), 1969-1990.

Moulaert, F., F. Martinelli, S. González \& E. Swyngedouw (2007) Introduction: Social innovation and governance in European cities urban development between path dependency and radical innovation. European Urban and Regional Studies, 14(3), pp. 195-209.

Mulgan G (2006) 'The process of social innovation', Innovations, 1(2), pp. 145-162.

Mulgan, G., S. Tucker, R. Ali and B. Sanders (2006) Social innovation: What it is, why it matters, how it can be accelerated, The Young Foundation, London.

Murray, R., J. Caulier-Grice and G. Mulgan (2010) The open book of social innovation. London, UK: NESTA and the Young Foundation.

Narayan, D. (2002) Empowerment and Poverty Reduction. Washington, DC: World Bank.

Narayan, D. (2005) Measuring Empowerment: Cross-disciplinary Perspectives. Washington, DC: World Bank.

Narayan, D., Chambers, R., Shah, M. K. \& Petesch, P. (2000a) Voices of the Poor: Crying Out for Change, World Bank Series, Oxford: Oxford University Press.

Narayan, D., Patel, R., Schafft, K., Rademacher, A. \& Koch-Schulte, S. (2000b) Voices of the Poor: Can Anyone Hear Us?, World Bank Series, Oxford: Oxford University Press.

Nicholls, A. and A. Murdock (2012) Social Innovation: Blurring Boundaries to Reconfigure Markets, London: Palgrave Macmillan.

Nilsson, W. O. (2003) Social Innovation: An Exploration of the Literature, McGill-Dupont Social Innovation Initiative, Montreal: McGill University, https://issuu.com/gfbertini/docs/social_innovation_-_an_exploration_of_the_literatu (accessed 1 Sep 2016).

North, D. (1990), Institutions, Institutional Change and Economic Performance, Cambridge: Cambridge University Press.

North, D. (2005), Understanding the Process of Economic Change, Princeton, NJ: Princeton University Press.

Oakley, P. (2001) Evaluating Empowerment: Reviewing the Concept and Practice, Oxford: INTRAC.

Ostrom, E. (2005) Understanding Institutional Diversity, Princeton, NJ: Princeton University Press. Pahl-Wostl, C. (2006) The importance of social learning in restoring the multifunctionality of rivers and floodplains, Ecology and society, 11(1), p.10.

Patel, S., S. Burra and C. d'Cruz (2001) 'Slum/shack dwellers international (SDI)-foundations to treetops', Environment and Urbanization, 13(2), pp. 45-59.

Paul, S. (1982) Managing Development Programs: The lessons of Success. Boulder, CO: Westview. 
Pel, B. and T. Bauler (2014) The institutionalization of social innovation: between transformation and capture, TRANSIT Governance Position Paper, Deliverable 2.2, TRANSIT: EU SSH.2013.3.2-1, accessed online 7 Oct http://www.transitsocialinnovation.eu/content/original/Book $\% 20$ covers/Local $\% 20 \mathrm{PDFs} / 110$ \%20Tranist $\% 20$ Position $\% 20$ Paper $\% 20 \mathrm{Pel} \% 20$ and $\% 20 \mathrm{Bauler} \% 20 \mathrm{The}^{\circ} \% 20$ insitutionalization $\% 20$ of $\% 20$ SI $\% 20$ between $\% 20$ transormation $\% 20$ and $\% 20$ capture $\% 20$ Transit $\% 20$ Del $\% 202 \% 202 \% 20$ 2014.pdf

Pelenc, J. M. Lompo, J. Ballet and J. Dubois (2013) Sustainable Human Development and the Capability Approach: Integrating Environment, Responsibility and Collective Agency, Journal of Human Development and Capabilities, 14 (1), pp. 77-94.

Pelenc, J., D. Bazile, and C. Ceruti (2015) 'Collective capability and collective agency for sustainability: A case study', Ecological economics, 118, pp. 226-239.

Perrini, F., C. Vurro and L.A. Costanzo (2010) 'A process-based view of social entrepreneurship: From opportunity identification to scaling-up social change in the case of San Patrignano', Entrepreneurship \& Regional Development: An International Journal, 22(6), pp. 515-534.

Phills, J., K. Deiglmeier and D. Miller (2008) 'Rediscovering Social Innovation', Stanford Social Innovation Review, 6(Fall), pp. 34-43.

Pick, S. and J. Sirkin (2010) Breaking the Poverty Cycle: The Human Basis for Sustainable Development. New York: Oxford University Press.

Pol, E. \& S. Ville (2009) 'Social innovation: Buzz word or enduring term?' Journal of SocioEconomics, 38(6), pp. 878-885.

Powell. W. and P.J. DiMaggio (eds.) (1991) The new institutionalism in organizational analysis, Chicago: The University of Chicago Press.

Putnam, R. (1993) Making Democracy Work: Civic Traditions in Modern Italy. Princeton: Princeton University Press.

Putnam, R. (2000) Bowling Alone: The Collapse and Revival of American Community. New York: Simon and Schuster.

Qizilbash, M. (2012) Utilitarianism, 'Adaptation' and Paternalism' in Adaptation, Poverty and Development: The Dynamics of Subjective Well-Being, D. Clark (ed.) Basingstoke: Palgrave Macmillan, pp. 35-60.

Ray, D. (2006) 'Aspirations, Poverty and Economic Change' in A. V. Banerjee, R. Bénabou and D. Mookherjee (eds) Understanding Poverty. Oxford: Oxford University Press: 409-443.

Rose, J. and R. Scheepers. (2001) Structuration Theory and Information System Development Frameworks for Practice. Paper presented at the 9th European Conference on Information Systems, Slovenia, June. Accessed online, 16 Oct 2015: http://citeseerx.ist.psu.edu/viewdoc/download?doi=10.1.1.129.3684\&rep=rep1\&type=pdf

Rowlands, J. (1997) Questioning Empowerment, Oxford: Oxfam. 
Schäpke, N. and F. Rauschmayer (2014) 'Going beyond efficiency: including altruistic motives in behavioral models for sustainability transitions to address sufficiency'. Sustainability: Science,

Practice, \& Policy, 10(1).

Schwartz, S. and J. Howard (1981) A normative decision-making model of altruism in J. Rushton and R. Sorrentino (eds.) Al-truism and Helping Behaviour, Hillsdale, NY: Erlbaum, pp. 189-211.

Sen, A. K. (1985) 'Well-Being, Agency and Freedom: the Dewey Lectures 1984', Journal of Philosophy, 82 (4), pp.169-221.

Sen, A. K. (1992) Inequality Reexamined. New York: Russell Sage Foundation.

Sen, A. K. (1999) Development as Freedom. Oxford: Oxford University Press.

Sen, A.K. (2002) 'Response to Commentaries', Studies in Comparative International Development, 37 (2), pp. 78-86.

Sen, A.K. (2004) 'Elements of a Theory of Human Rights', Philosophy and Public Affairs, 32, pp. 315-356.

Sen, A.K. (2008) 'The Idea of Justice', Journal of Human Development, 9 (3), pp 331-342.

Sen, A.K. (2009) The Idea of Justice, Harvard University Press, Cambridge MA.

Seo, M.G. and W.E.D. Creed (2002) 'Institutional Contradictions, Praxis, and Institutional Change: A Dialectical Perspective', Academy of Management Review, 27 (2), pp.222-247.

Sewell, W.H. (1992) 'A theory of structure: Duality, agency and transformation', American Journal of Sociology, 98, pp. 1-29.

Seyfang, G. and A. Haxeltine (2012) 'Growing grassroots innovations: Exploring the role of community-based initiatives in governing sustainable energy transitions', Environment and Planning C: Government and Policy, 30(3), pp. 381-400.

Seyfang, G. and A. Smith (2007) Grassroots innovations for Sustainable Development: Towards a New Research and Policy Agenda, Environmental Politics, 16 (4), pp. 584-603.

Sharra, R. and M. Nyssens (2010) Social innovation: An interdisciplinary and critical review of the concept. Louvain, Belgium: Université Catholique de Louvain.

Stewart, F. (2005) 'Groups and Capabilities', Journal of Human Development, 6 (2) pp.185-204.

Taliaferro, M B (1991) 'The Myth of Empowerment', Journal of Negro Education, 60 (1), pp. 1-2.

Thornton, P., J. Devine, P. Houtzager, D. Wright and S. Razario (2000) Partners in Development: A Review of Big NGOs in Bangladesh. Dhaka: Report to DFID.

Thorp, R., Stewart, F. and Heyer, J. (2005) 'When and How Far is Group Formation a Route Out of Chronic Poverty?’ World Development, 33 (6) pp. 907-920. 
Tiwari, M. and S. Ibrahim (2012) 'Sustainable Human Development at Grassroots: Different Contexts, Similar Ingredients?’ Oxford Development Studies, 40 (1), pp. 69-85.

United Nations Development Programme (UNDP) Human Development Reports 1990-2015, New York: United Nations Development Programme.

Uphoff, N., M.J. Esman and A. Krishna (eds.) (1998) Reason for Success: Learning from instructive experiences in rural development, West Hartford, CT: Kumarian.

VeneKlasen, L. and Miller, V. (2002) A New Weave of People, Power and Politics: the Action Guide for Advocacy and Citizen Participation, Oklahoma: World Neighbours.

Volkert, J. (2013) Concepts of agency, sustainable human development (SHD) and collective abilities, Maiyteree 22, pp. 4-8.

Zahra, S. A., E. Gedajlovic, D. O. Neubaum and J. M. Shulman (2009) 'A typology of social entrepreneurs: Motives, search processes and ethical challenges', Journal of Business Venturing, 24(5), pp. 519-532.

Ziegler R., B. H. K. Karanja \& C. Dietsche (2013) 'Toilet Monuments: An Investigation of Innovation for Human Development', Journal of Human Development and Capabilities, 14 (3), pp. 420-440.

Ziegler, R. (2010) 'Innovations in Doing and Being: Capability Innovations at the Intersection of Schumpeterian Political Economy and Human Development', Journal of Social Entrepreneurship, 1. (2), pp. 255-272.

Ziegler, R. (2013) 'Real Social Contracts for Sustainability? Philosophical and Political Implications of Social Agreement in Circumstances of Poverty and Degraded Ecosystems', Public Reason 5 (2), pp. 3-20 
Figure 1 - The 3C-Model for Grassroots-led Development individual and communal well-being

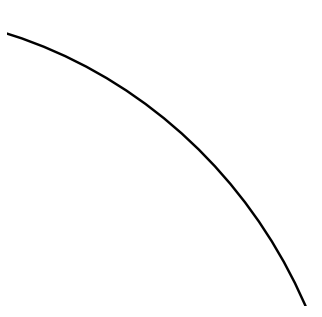

Willingness to Act

Collaboration with External Inducing local institutional Actors: state, donors \& NGOs
Individually to Improve one's own living conditions
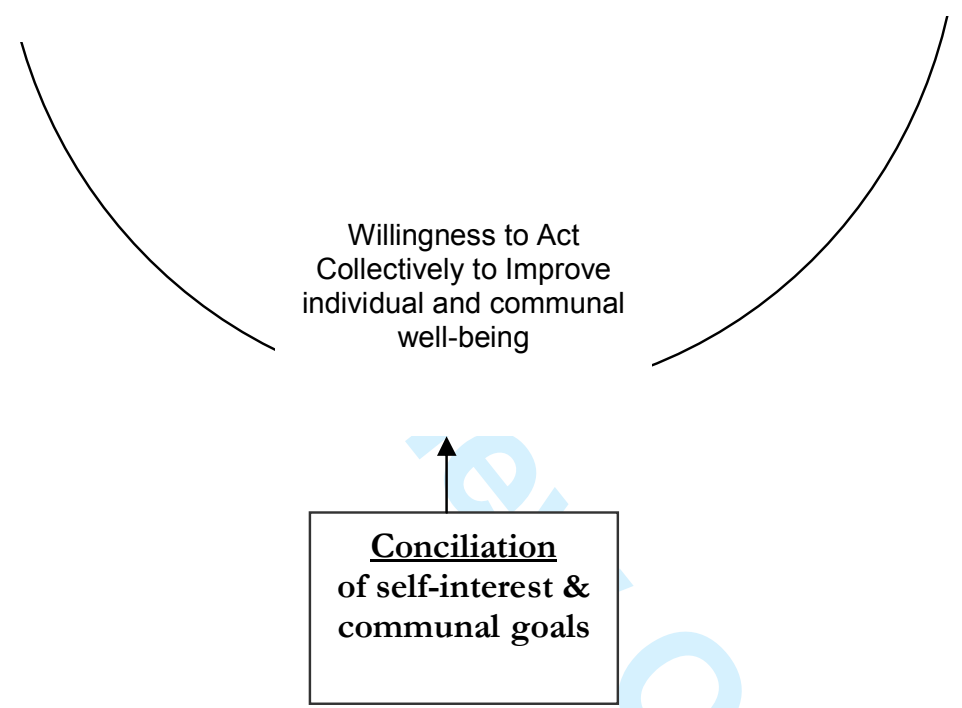

Conscientization through critical reflection 